\title{
POČECI HRVATSKE ROMOLOGIJE: OD FILIPA IVANA VEZDINA DO FRANJE FANCEVA
}

\section{DANIJEL VOJAK}

Institut društvenih znanosti "Ivo Pilar"

10000 Zagreb, Marulićev trg 19/1

danijel.vojak@pilar.hr

iD orcid.org/0000-0003-2545-2225
DOI: $10.17234 /$ SEC.29.14

Pregledni rad

Primljeno: 1. 3. 2017.

Prihvaćeno: 28. 6. 2017.

Ovaj rad nalazi se u otvorenom pristupu i može se distribuirati u skladu s odredbama licencije CC BY-NC-ND 4.0 HR

Romologija kao posebna znanstvena disciplina usmjerena je na proučavanje ukupnosti romske povijesti $i$ kulture. Naseljavanje romskog stanovništva u europske zemlje od 14. stoljeća potaknuo je i interes znanstvenika za njihovo proučavanje. Tako su prvi istraživački prinosi o povijesti i kulturi Roma objavljeni u 16. stoljeću i to kod zapadnoeuropskih znanstvenika. $U$ drugoj polovini 18. stoljeća zabilježeni su prvi znanstveni prilozi o Romima od pojedinaca koji su bili podrijetlom Hrvati ili su tada živjeli na području hrvatskih zemalja.. U tom kontekstu mogu se promatrati doprinosi Filipa Ivana Vezdina i Ivana Škrleca Lomničkog. U prvoj polovini 19. stoljeća slijedili su doprinosi Antuna Mihanovića i Spiridona Jovića, dok je u drugoj polovini 19. stoljeća uočljiv pojačani znanstveni interes za proučavanje Roma, i to kod Mijata Stojanovića, Mare Čop Marlet, Franje Kuhača, Emilija Laszowskog, Friedricha S. Kraussa, Ivana Broza, Ljudevita Draškovića i Ferde Hefelea. Sustavna etnografska istraživanja na kraju 19. stoljeća provodio je Odbor za narodni život i običaje Jugoslavenske akademije znanosti i umjetnosti, unutar kojeg su mnogi istraživači, poput Luke Lukića, Vatroslava Rožića i Vladimira Ardalića, značajno pridonijeli razumijevanju povijesti, kulture i jezika Roma. Prvo romološko razdoblje u Hrvatskoj završilo je s Prvim svjetskim ratom i djelima Milana Mizlera i Franje Fanceva.

Ključne riječi: Romi, Romologija, Hrvatska, povijest, znanost

\section{UVOD}

Od 1990-ih primjetan je razvoj znanstvenih istraživanja o Romima u Europi te tako neki znanstvenici poput Davida Mayalla navode kako je otada broj znanstvenih istraživanja unutar romskih studija toliko poraslo da se sada oni sastoje od brojnih akademskih disciplina i znanstvenih interesa te 
je pritom uočen impresivan razvoj u privlačenju brojnih i raznih stručnjaka koji se sve više bave širim i raznolikim područjima, poput pedagogije, sociologije, antropologije i dr. (Mayall 2004:26, 29). U tom kontekstu neki znanstvenici, poput Wima Willemsa, primjećuju određenu površnost u dotadašnjem proučavanju Roma što se odnosilo većinom na folkloristička i lingvistička proučavanja. On zatim ističe kako je potrebno promijeniti diskurs istraživanja prema Romima i to u smjeru da se komparativnom metodologijom proučava njihovu društvenu mobilnost i izgradnju njihova identiteta (Willems 1997:308-309). U kontekstu romoloških historiografskih istraživanja primjetan je porast istraživanja stradanja Roma u Drugom svjetskom ratu o čemu najbolje svjedoči i letimičan uvid u bibliografiju radova o stradanju Roma u europskim zemljama za vrijeme Drugoga svjetskog rata koje je krajem 2015. godine izdala International Holocaust Remembrance Alliance (About i Abakunova 2015; Baumgartner et al. 2015). Na margini ovog pojačanoga romološkog istraživanja bila su ona u Hrvatskoj gdje je u posljednjih nekoliko godina primjetan određeni pomak u istraživanju povijesti Roma u Hrvatskoj i to napose u razdoblju Drugoga svjetskog rata (Vojak 2010, 2014:195, 2016:608-610). No, unatoč ovom pomaku, i dalje se može smatrati da je povijest jedne od najstarijih manjinskih skupina u Hrvatskoj nedovoljno istražena tema u hrvatskoj historiografiji. Tako je i danas gotovo nepoznato romsko doseljavanje i život u kasnosrednjovjekovnom i ranonovovjekovnom razdoblju na hrvatskim područjima. Istodobno, slične 'rupe' u povijesti Roma u Hrvatskoj primjetne su i za suvremenije razdoblje, poput vremena socijalističke Jugoslavije. U tom kontekstu nameće se potreba sustavnijeg istraživanja povijesti ove manjinske skupine, a jedan od prvih koraka u ostvarenju toga cilja jest istražiti pojedince koji su se bavili ovo tematikom. Upravo su ti pojedinci u svom razdoblju bili zaslužni za razumijevanje povijesti, kulture, jezika i običaja romskoga manjinskog stanovništva. U analizi su obuhvaćeni samo znanstveni prilozi o Romima, ili, pobliže rečeno, samo oni prilozi za koje se može smatrati da su nastali unutar određene znanstvene discipline. Istodobno, ovim radom nisu obuhvaćeni književni i publicistički prilozi i to ponajprije zbog njihova znatnog broja što nameće potrebu njihove zasebne analize. 


\section{UKRATKO O RAZVOJU ROMOLOGIJE U EUROPI DO PRVOGA SVJETSKOG RATA}

Ponajprije je potrebno definirati romologiju koju neki nazivaju romskim studijima ili antropologijom o Romima, kao posebnu znanstvenu disciplinu koja obuhvaća pitanja proučavanja života i običaja Roma; pritom je istaknuto kako su predmet romologije Romi i njihov život ili grupa ljudi koji po svom etničkom i povijesnom podrijetlu te socijalnim, kulturnim, jezičnim i drugim osobitostima predstavljaju jednu posebnu društvenu zajednicu (Đorđević 2007:500, 2010:18; Hrvatski enciklopedijski rječnik 2003:1142; Veliki rječnik hrvatskog jezika 2003:1349). Neki znanstvenici, poput Alenke Janko Spreizer, razlikuju termin ciganologija (prevedeni termin s engleskog jezika gypsiology i na francuskom jezikom tsiganologues) od termina romologija, smatrajući ciganologiju za stariji i tradicionalniji znanstveni pristup proučavanju Roma (naglasak na folkloristiku i lingvistiku), za razliku od romologije ili romskih studija koji su nastali kao reakcija na uskost (ograničenost) "starijih studija" o Romima te pritom obuhvaćaju proučavanja Roma u širim (brojnijim) znanstvenim disciplinama (indologiju, etnologiju, arheologiju, sociologiju, povijest, etnomuzikologiju i sl.) (Janko Spreizer 2010:97-104). Slično njoj primjećuje Willems kritizirajući ustanovljenje ciganologije kao legitimnoga stručnog područja, a to se posebno odnosi na rana "ciganološka" djela koja on kritizira kao nepouzdana, plagirana, generalizirana sa slabim ili dubioznim tezama, a sve je to posljedica nedostatnosti u obrazovanju samih stručnjaka, statističkih netočnosti, manjka komparacije s drugim znanstvenim disciplinama. Willems nadalje kritizira objektivnost u radu tih stručnjaka kao posljedicu njihova entuzijazma, aktivizma i političke korektnosti (Mayall 2004:25). Nakon Drugoga svjetskog rata, posebice od 1960-ih i 1970-ih, ciganski studiji odmiču se od "loše definirane mješavine folklorizma (amaterizma) i lingvistike s dominacijom folklorista, antropologa, lingvista, antikvara i amaterskih povjesničara" i pritom se počinje isticati prevladavanje stručnjaka s područja sociologije i politologije s osloncem i dalje na tradiciju (ibid. 26). Osim toga, zanimljivo je istaknuti interdisciplinarnost kao opće mjesto romologije kao discipline u izgradnji, a pritom podrazumijeva "prožetost i suradnju” među znanstvenim disciplinama. Istodobno, za romologiju neki smatraju kako ona nije i multidisciplinarna, jer se više znanstvenih disciplina usporedno ne bavi 
određenom tematikom vezanom uz Rome (Đorđević 2010:19, 29, 31). Nadalje, Đorđević kritizira etnologiju kao "majku zajednici romologije" jer da ona svodi Rome, njihov život i kulturu na folklor, kao povijesni okamenjeni objekt prikazivan u muzejima i na izložbama, a pritom ne obuhvaća romsku dinamičnost i emancipaciju (ibid. 20). Potrebno je ukratko se osvrnuti na rad nekih od važnijih europskih znanstvenika koji su se bavili proučavanjem povijesti, kulture, običaja i jezika Roma kako bi se moglo kontekstualizirati romološke znanstvene priloge čiji su autori hrvatskog podrijetla ili su živjeli na hrvatskim područjima.

Naseljavanje romskog stanovništva u srednjovjekovnoj Europi, između ostalog, probudilo je određenu razinu znatiželje tamošnjih znanstvenika. Među prvim takvim znanstvenicima ističu se engleski lingvist Andrew Boorde koji je sredinom 16. stoljeća analizirao romski jezik (Grant 1999:65; Hancock 1994:3604; Jauk-Pinhak 1989:12). Prva sustavnija romološka istraživanja započinju krajem 18. stoljeća $\mathrm{s}$ lingvističkim analizama Johanna Carla Christopha Rüdigera i Heinricha Moritza Gottlieba Grellmanna koji su nastojali pobiti dotadašnje uvriježeno tumačenje o egipatskom podrijetlu Roma i dokazati njihovo indijsko podrijetlo (Jauk-Pinhak 1989:13; Matras 1999:89-116). Tako su neki znanstvenici, poput Wima Willemsa, upravo Grellmanna istaknuli kao "oca ciganskih studija" navodeći kako je on postavio temelje za znanstvena proučavanja Roma te je znatno utjecao na znanstvena istraživanja o Romima u 19. stoljeću (Mayall 2004:34).

U 19. stoljeću znanstvena su se istraživanja većinom usredotočila na jezik Roma gdje su značajni radovi Augusta Friedricha Potta i Franca Miklošiča u kojima su istražili povezanost romskog jezika sa sanskrtom te istražili leksičke posebnosti unutar romskog jezika. Ne želeći detaljnije analizirati razvoj romoloških istraživanja, potrebno je ukratko spomenuti kako se od sredine 19. stoljeća romološka istraživanja djelomično odmiču od lingvističkog područja te se nastoje istražiti kultura i običaji Roma u pojedinim državama. Takva istraživanja u Austro-Ugarskoj provode nadvojvoda Josip Habsburški i Antal Herrmann, u Velikoj Britaniji George Henry Borrow, u Njemačkoj Heinrich von Wlislocki i dr. Svoj institucionalni oblik romološka istraživanja dobivaju 1888. kada je u Edinburghu osnovano The Gypsy Lore Society koje se bavi proučavanjem i zaštitom romske kulture i jezika (Vojak 2010:217). 
Potrebno je napomenuti kako su neke europske države, posebice Njemačka i Italija, od druge polovine 19. stoljeća provodile nasilnorepresivnuiasimilacijskupolitikuprema Romima. Utomkontekstuosnovana je Ciganska informativna služba (njem. Zigeuenernachrichtendienst ili Zigeunerzentrale) 1899. u sklopu münchenske policije što se može smatrati prvim pokušajem institucionalnog rješavanja onoga što se tada nazivalo "ciganskim pitanjem". Alfred Dillmann je, kao voditelj ovog ureda, izdao 1905. Zigeuner-Buch u kojoj je objavio detalje o životu i podrijetlu više od 3500 Roma te time pružio znanstvenu podlogu kasnijim (nacističkim) njemačkim političarima i znanstvenicima za rješavanje "ciganskog pitanja" (Heuss 2006:8-9; Fraser 1995:251-252; Margalit 2002:30-31; Lucassen et al. 1998:85-87). Upravo Dillmannovo djelo mora se shvatiti u kontekstu izraženog utjecaja državnih vlasti na razvoj poučavanja o Romima. Na tom tragu mogu se vidjeti eugenička istraživanja Roberta Rittera, nacističkoga rasnog znanstvenika, koji je svojim istraživanjem izradio rasnu klasifikaciju Roma, a pritom je pružao znanstvenu podlogu za političko-policijska nastojanja rješavanja navedene problematike na rasnim osnovama prema "neželjenim skupinama" poput Roma (Willems 1997:215; Heuss 2006:18 19; Fraser 1995:257-259). Willems upravo Rittera ističe kao jednog od trojice znanstvenika, uz Heinricha Grellmanna i Georgea Borrowa, koji su bili predvodnici novih smjerova u znanstvenim istraživanjima o Romima (Willems 1997:196-292).

\section{POČECI HRVATSKE ROMOLOGIJE}

Slijedeći teorijske okvire definicije romologije, potrebno je istaknuti kako će u ovom radu biti analizirani samo oni radovi u kojima je uočljiv doprinos određenoga hrvatskog znanstvenika u proučavanju povijesti, kulture, jezika i običaja Roma. Tako uzgredno spominjanje Roma u određenim radovima, kao ni razni književni prilozi, nisu uvršteni u rad, iako se ne treba zanemariti i njihova vrijednost.

Znanstvena istraživanja Filipa Ivana Vezdina o romskom jeziku mogu se smatrati početkom hrvatske romologije. Njegovo hrvatsko podrijetlo iz Donje Austrije, a kao takav je u hrvatskoj znanosti istaknut kao "gradišćanski Hrvat”, može ga uvrstiti među prve (Sekulić 1999:191). On je u djelu Viaggio alle Indie Orientali, objavljenom 1796. u Rimu, 
opisao svoje putovanje u Indiju, a znanstveni karakter ovog putopisa upravo čini njegova lingvistička analitička komparativnost sanskrta $\mathrm{s}$ grčkim i latinskim jezikom (ibid. 192). U tom je djelu, između ostalog, pisao i o Romima kao kasti parija u Indiji, odakle su, zbog progona Timura u Indiji, započeli migrirati u smjeru Europe. On se osvrnuo na teze Heinricha Moritza Gottlieba Grellmanna i složio se s njegovim promišljanjem o indijskom podrijetlu Roma, jer je istaknuo kako je u romskom jeziku primjetan znatan utjecaj sanskrta. Istodobno, kritizirao je teze o egipatskom podrijetlu Roma, ponajviše jer je smatrao kako ne postoje sličnosti u jezicima iz Starog Egipta i Indije te je zastupao tezu o mogućem dolasku dijela Roma na egipatsko područje, odakle su migrirali u smjeru Europe (Bartolomeo 1796:28, 259-260, 268). Zanimljivo je napomenuti kako su priređivači ovog djela na francuski jezik 1808., poput Johanna Reinholda Forstera, oštro kritizirali Vezdinovo promišljanje o indijskom podrijetlu Roma (Jauk-Pinhak 1989:14).

Suvremenik Vezdina bio je Nikola Škrlec Lomnički koji se rodio i umro u Zagrebu (1729. - 1799.), a obavljao je niz javnih funkcija (pobočnik podbana Ivana Raucha, vrhovni kraljevski blagajnik, kraljevski protonotar, savjetnik i ravnatelj pisarnice Hrvatskoga kraljevskog vijeća, viši ravnatelj škola i studija u Hrvatskoj, izvjestitelj/poslanik Kraljevine Hrvatske u Ugarskom namjesničkom vijeću i veliki župan Zagrebačke županije) (Lučić 2001:101-111). On je krajem 18. stoljeća u trima spisima analizirao društveni i gospodarski položaj Roma u Ugarskoj što se može smatrati prvim ekonomskim romološkim prinosom jednoga hrvatskog znanstvenika. U prvom takvom spisu Status actualis (Škrlec Lomnički 2007:379-681) tek uzgredno spominje "lijenost" Roma, dok u spisu Descriptio (Erceg 2000:41-178) prikazuje neuspješnost dotadašnjih reformskih odredaba o Romima, navodeći kako te odredbe nisu oblikovane u poseban zakon i kako ih lokalne vlasti nisu provodile. Škrlec se, između ostalog, u navedenu spisu zalagao za zapošljavanje besposličara $i$ iskorjenjivanje prosjačenja. Potrebno je imati na umu kako se smatra da je spis Status actualis nastao prije spisa Descriptio kao prvotna verzija njegova elaborata o ekonomskim prilikama Ugarske. Zatim je poslije bio prerađen i oblikovan u spis Descriptio koji je vjerojatno napisao 1791. za vrijeme zasjedanja Ugarskog sabora (Vranjican 2007:14; Lunaček 1999:445). Najviše je o Romima pisao u spisu Projectum (Škrlec Lomnički 
1999:89-418) u kojem je predlagao da se Romima omogući obrtničko obrazovanje i zapošljavanje, da im se zabrani nomadski načina života čime bi se spriječio njihov kriminalitet (ibid. 101). Ovi prijedlozi, temeljeni na tada suvremenim načelima kameralizma, podudaraju se s reformskim odredbama vladara Marije Terezije i Josipa II. koji su Rome pokušavali stalno naseliti, obrazovati, zaposliti te ograničiti njihove nomadske običaje (Fraser 1995:156; Crowe 1996:73-76; Vojak 2013a:197-215). Drugačije rečeno, terzijanska i jozefinska reformska politika prema Romima imala je cilj pretvoriti ih u 'korisne' članove društva, a posebice kod Josipa II. ona je bila usmjerena i kao jedno od sredstva borbe protiv siromaštva (Willems 1997:28-34).

Sljedeći znanstvenik u Hrvatskoj koji je pisao o Romima bio je Antun Mihanović koji je 1823. u bečkom časopisu Archiv für Geschichte, Statistik, Literatur und Kunst objavio rad naslovljen Die Zigeuner. U radu se ukratko osvrnuo na pitanje odnosa indijskog podrijetla romskog jezika; pritom je primjetan utjecaj Rüdigera i Grellmanna vezano uz indijsko podrijetlo romskog jezika (Očak 1998:140, 142; Jembrih 1996:125; Vodnik 1910:13).

Dvanaest godina kasnije Spiridon Jović objavljuje u Beču djelo Ethnographisches Gemählde der slavonischen Militärgränze, oder ausführliche Darstellung der Lage, Beschaffenheit und politischen Verfassung des Landes, dann der Lebensart, Sitten, Gebräuche, der geistigen Bildung und des Charakters seiner Bewohner. Ein Beitrag zur Länder- und Völkerkunde des österreichischen Kaiserstaates (Jović 2004). Iz naslova djela uočljiva je usmjerenost autora na geografsku, povijesnu, političku, etnološku i antropološku analizu stanovništva u Vojnoj krajini na slavonskom području u prvoj polovini 19. stoljeća. Između ostalog, Jović je u svom radu analizirao položaj Roma i njihovo podrijetlo ističući Grellmannovu tezu o indijskom podrijetlu Roma. Nadalje, pisao je o romskom naseljavanju Vojne krajine i o trenutačnom društvenom položaju, da bi zatim analizirao njihov fizički izgled, način života i običaja (odnos prema braku, način odijevanja, odgajanje djece), zanimanja, odnos prema seoskom stanovništvu (ibid. 104). Između ostalog, Jović navodi kako

"kao Spartanac svoje helote, kao Indus svoje parije - tako i Mađar nipodaštava, prezire, gnuša se svojih Cigana. Ovaj zagonetni narod čami u Mađarskoj kao god i u drugim krajevima Europe gde ga još 
ima, u provaliji moralne pokvarenosti, a da se nikada nije potrudio da pođe putem popravljanja i da postane vredan poštovanja ljudi” (Jović 2004:104).

Nadalje, potrebno je spomenuti radove Mijata Stojanovića o narodnoj baštini sredinom istog stoljeća, posebice u narodnim pripovijetkama i poslovicama u Hrvatskoj i Slavoniji, u kojima je zabilježio znatan broj onih koji se odnose na Rome. Stojanović je u nekoliko svojih djela bilježio usmenu narodnu baštinu i na osnovi toga nastojao "poučavati i obrazovati puk". Tako u je djelu Sbirka narodnih poslovicah, riečih i izrazah zabilježio brojne narodne poslovice u kojima se spominju Romi ili ih je zabilježio od Roma. Poslovice su popraćene njegovim pojašnjenjem što omogućava njihovo bolje razumijevanje, a pritom otkrivaju na koji je način neromsko stanovništvo percipiralo i odnosilo se prema Romima i obratno - na koji je način romsko stanovništvo percipiralo i odnosilo se prema ne-Romima (Stojanović 1866). Najviše je o Romima objavio u djelu Slike iz domaćega života slavonskog naroda $i$ iz prirode gdje je pisao o njihovu životu u Slavoniji i Srijemu i na području tada ukinute Vojne krajine. Osim toga, donio je nekoliko pripovijetki o Romima, koje je sabrao 1832. u Lukavčevu Šamcu (Slavonski Šamac) (Stojanović 1881).

U drugoj polovini 19. stoljeća Mara Čop Marlet koju neki smatraju prvom hrvatskom etnografkinjom, objavila je nekoliko etnografskih radova o Romima. Između ostalih, značajan je njezin rad Die Zigeuner unter den Südslawen u mađarskom časopisu Ethnologische Mitteilungen aus Ungarn u kojem je analizirala način života, zanimanja i jezik Roma. Upravo je taj časopis smatran "kontinentalnom protutežom" na engleski časopis Journal of the Gypsy Lore Society (Willems 1997:188). Osim toga, objavila je knjigu Südslawische Frauen. Auf Höhen und Tiefen der Balkanländer u kojoj je analizirala društveni položaj Romkinje među južnoslavenskim narodima (Žura Vrkić 2003a:277, 292-295). Zanimljivo je primijetiti kako je ona bila članica triju etnografskih društava: francuskog Académie internationale des Palmiers, engleskog The Gypsy Lore Society (imenovalo ju je dopisnim počasnim članom) i mađarskog Magyar Néprajzi Társaság, a ona je bila članica hrvatskog ogranka toga društva zajedno s Ivanom Bojničićom i Friedrichom S. (Salomon) Kraussom te pod predsjedanjem Imre Josipovića (Žura Vrkić 2003b:15-16). Sudjelujući u radu triju etnografskih društava i 
surađujući s brojnim istraživačima običaja, jezika i povijesti Roma, poput nadvojvode Josipa Habsburškog, Antal Herrmann i Franca Miklošiča, ona je uspjela pratiti i sudjelovati u razvoju suvremene romologije.

Jedan od kolega Mare Čop Marlet s kojim je surađivala na proučavanju kulture i običaja Roma bio je Franjo Kuhač. On je opisivao njihove običaje, odnose prema slobodi i vjeri te njihovo obrtničko, trgovačko i umjetničko djelovanje. Između ostalog, objavio je pjesme o Romima objavio u četverosvešćanom djelu Južno-slovjenske narodne popievke (Kuhač 1904:31, 1878:113, 161, 1880:281-283, 1881:109-110, 220-221). O romskoj glazbenoj tradiciji pisao je i u djelima Porietlo $i$ umieće hrvatskih pučkih pjevača i glazbara, Iz "sbirke jugoslavenskih narodnih napjeva", Budnica Trenkovih pandura (po glasbovanju bosanskih cigana u kajde stavio i za glasovir priredio Franjo Š. Kuhač) i Pjevanka: sto dječjih popievaka za jedno grlo (Kuhač 1896:12, 1875:268, 1885:35, 38-39). Zanimljivo je i Kuhačevo djelo Narodne osebine u gestama i karakteristika pojedinih naroda u kojem se osvrće i na Rome (Kuhač 1907:220, 223, 232, 249), no pritom ne treba smetnuti s uma kako je Kuhač u svojim proučavanjima Roma surađivao s istaknutim tadašnjim romolozima, poput nadvojvode Josipa Habsburškog, o čemu je Kuhač pisao navodeći kako

"prejasni nadvojvoda Josip poslao mi je iz Alcsutta, svoju gramatiku ciganskog jezika, misleći da sam ja ciganolog, pošto sam nešto pisao o hrvatskim ciganima. Njegovoj želji, da ja u privatnom pismu izrečem sud o toj gramatici, zadovoljio sam" (Kuhač 1904:14.).

Manje je poznato kako je i Emilij Laszowski bio još jedan od znanstvenika iz kruga Mare Čop Marlet, o čemu je on ostavio bilješku u svom neobjavljenom tekstu Uspomene na ljude koji se čuva u osobnom arhivskom fondu u Hrvatskom državnom arhivu. Laszowski je, opisujući djelovanje Mare Čop Marlet, istaknuo kako

"neko je vrijeme proučavala jezik, običaje i život Cigana i tako se je približila nadvojvodi Josipu, koji se je na svojim madjarskim imanjima mnogo bavio ciganskim problemom. Nastojao je, da Cigane stalno naseli na svojim imanjima. Dao im je zemlje, posagradio kućice, dao im gospodarsko oruđe, marve i drugo. Ali to mu nije uspjelo, jer su naseljeni Cigani odbjegavali u svoj stari nomadski život. Kod 
toga posla pomagala mu Marlet nekoliko godina, i sama proučavala Cigane i naučila se je i njihov jezik. Nju opet je u tom poslu pomagao naš muzikolog Franjo Ks. Kuhač s ciganskim pjesmama, koje je on sakupio" (Hrvatski državni arhiv, HR-HDA-806, Osobni fond Emil Laszowski, 1.5.1.17. Uspomene na ljude, Mara Čop-Marlet).

\section{Laszowski zatim ističe utjecaj Mare Čop Marlet na njegovo romološko djelovanje navodeći kako}

“kad sam g. 1890. stanovao u [?] kući u Karlovcu upoznao sam ČopMarlet-ovku i s njom bio u marnom saobraćaju, jer mi je ona svojim duhom vrlo imponirala. Mnogo mi je [nečitko, op. a.] o nastojanju nadvojvode Josipa, da riješi 'cigansko pitanje'. Dala mi je na čitanje i neka njegova pisma, koja su sadržavala njegove osnove s Ciganima. To mi je dalo impuls, da me je to pitanje počelo zanimati, te sam $\mathrm{g}$. 1894. u Narod. Novinama (b 211) napisao kratku 'Poviesnu crticu o Ciganima,*" (Hrvatski državni arhiv, HR-HDA-806, Osobni fond Emil Laszowski, 1.5.1.17. Uspomene na ljude, Mara Čop-Marlet).

Iz navedenog se može vidjeti kako je na romološki rad Laszowskog izravno utjecala Mara Čop Marlet koja tada pripada jednom uskom akademskom romološkom europskom krugu. Laszowski je dio svojih istraživanja objavio 1894. u jednom manjem članku naslovljenom Povjestna crtica o Ciganima u Narodnim novinama i taj se tekst može smatrati prvim hrvatskim historiografskim radom o Romima (Laszowski 1894:4-5).

Friedrich S. Krauss pripadao je skupini znanstvenika koji su se, između ostalih, bavili i proučavanjem povijesti i kulture Roma. Tako je bio hrvatski predstavnik mađarskog društva Magyar Néprajzi Társaság. On je 1907. u Leipzigu objavio Zigeunerhumor: 250 Schnurren, Schwänke und Märchen u kojem je pisao o romskom humoru te suživotu između Roma, Hrvata i Srba (Krauss 1995:230-242). Krauss je u predgovoru ovog djela istaknuo kako mu je namjera bila prikazati pozitivne strane romskog života i običaje smatrajući kako su Romi "daleko bolji od glasa koji ih prati" (Krauss 1907:V). Zatim je usko surađivao sa srpskim

* “... O Ciganima imam prikupljen prilični materijal...” 
etnologom Tihomirom Đorđevićem i s poljskim antropologom Isidoreom Kopernickim, profesorom antropologije na krakovskom sveučilištu. Krauss je s Đorđevićem surađivao na analizi romskog jezika i folklora Roma u Srbiji, a pritom je sam priznao kako je mnogo naučio o romskom jeziku i folkloru (ibid.:VI). Nadalje, Krauss je prikupio leksičku građu Roma u "ciganskoj mahali" u Derventi i prikupljeni materijal predao Kopernickom koji je zatim analizirao i objavio građu 1889. u radu The Dialect of the Bosnian Gypsies $\mathrm{u}$ Journal of the Gypsy Lore Society (Kopernicki 1889:125). Nadalje, Krauss u djelu Die vereinigten Königreiche Kroatien und Slavonien opisuje romsko naselje u okolici Našica ističući njihov način života, običaje i zanimanja (Krauss 1999). U nekoliko drugih djela piše dijelom i o Romima, poput knjige Smailagić Meho u kojoj se osvrće na "Bijele Cigane" u Bosni i Hercegovini (Krauss 1886). Kasniji znanstvenici ističu njegov prinos razvoju metodologije folklora i komparativne etnologije, i to posebice na području istraživanja odnosa neromskog i romskog stanovništva, ističući kako se njihova kultura međusobno prožimala (utjecala jedna na drugu) što pokazuju međusobne sličnosti u običajima, imaginariju, narativima i oblicima društvene interakcije (Williams 1997:188-189).

Ivan Broz, istaknuti hrvatski jezikoslovac i književni povjesničar, uz Antuna Mihanovića, bio je među prvim hrvatskim znanstvenicima koji su pisali o posebnosti romskog jezika. Broz je o tome pisao u djelu Crtice iz hrvatske književnosti, analizirajući najstarije hrvatske jezične i književne spomenike, a osvrnuo se i na posebnost romskog jezika i njegovu sličnost sanskrtu (Broz 1886:45-46). Između ostalog, Broz primjećuje kako

"ko bi prepoznao u Ciganina naše srodnike, ko bi rekao, da je ciganski jezik srodan u vrlo blizu sa sanskrtom (...) sve je to pokazala u najnovije doba nauka, koja je našla Ciganima domovinu, otkrila putove, kojima su zašli medju evropski svijet, i odredila im mjesto u nizu naroda. Znanost ne prezire ni sirote Ciganina!" (Broz 1886:45-46).

Ferdo Hefele bio je jedan od značajnijih hrvatskih pedagoga i etnografa, a pritom je objavio stotinjak pedagoških, etnografskih i kulturnopovijesnih stručnih radova $\mathrm{i}$ istaknuo se kao skupljač hrvatske folklorne građe i obrtnog nazivlja (Pleše 2002). On je krajem 19. stoljeća objavio 
nekoliko radova iz povijesti, kulture i običaja Roma. Prvi takav rad objavio je u časopisu Vienac, naslovljen Koritari, u kojem obrađuje romsku skupinu rumunjskih Roma - Bajaša koji su tada nazivani Koritarima, a danas čine skupinu Bajaši koja se razlikuje od drugih romskih skupina, jer su dio Vlaških Roma i govore starorumunjskim dijalektom ljimba d bjaš (Hrvatić i Ivančić 2000:257; Vojak 2013b:30). Hefele u radu nastoji problematizirati pitanje etničkog identiteta Koritara između romskog i rumunjskog identiteta, a o njemu je raspravljao s rumunjskim povjesničarom Nicolaem Densușianuom (Hefele 1890:742-743).

Upravo o pitanju etničkog identiteta kod Koritara raspravljao je Hefele s anonimno potpisanim "bosanskim Hrvatom" u Glasu Hercegovca u siječnju i veljači 1891. godine. "Bosanski Hrvat" kritizirao je Hefeleovo pisanje o Koritarima u Viencu posebno se ne slažući s tezom da oni žive u Hrvatskom primorju i pritom ih poistovjećuje s pravoslavnim "karavlaškim" i/ili “bugarskim” stanovništvom u Bosni (Bosanski Hrvat 1891: 2). Hefale je na navedene kritike uzvratio osobnim primjerima u susretima s Koritarima, posebice u Srbiji, napominjući kako je riječ o skupini koja je rimokatoličke vjeroispovijesti i rumunjskoga lingvističkog podrijetla (Hefele 1891:1-2). Tri godine kasnije Hefele je u Narodnim novinama objavio članak Nešto o ciganluku u kojem je analizirao društvena, gospodarska i vjerska obilježja tadašnjih Roma u Hrvatskoj i Slavoniji, razlikujući dvije skupine: "Bijeli Cigani” i “Crni Cigani”. Osim toga, donosi nekoliko primjera romskih pjesama i pripovijetki. Hefele ističe na kraju rada kako mu je namjera bila upoznati čitatelje sa "zanemarenim i zapuštenim svijetom" Roma, uz napomenu kako se nada da će Romi biti stalno naseljeni i marljivi dio stanovništva Hrvatske (Hefele 1894:4). Hefele zatim 1905. u Samoborskom listu objavljuje članak Koritari u kojem opisuje marljivost Koritara na samoborskom području gdje su se bavili izradom korita i drugih drvenih predmeta za kućanstvo. Osim toga, opisuje društveni i gospodarski život Koritara u Hrvatskoj i okolnim zemljama (Bosni i Hercegovini i Srbiji) donoseći nekoliko primjera koritarskih pjesama (Hefele 1905:1-2).

Hefelov suvremenik Ljudevit Drašković također se bavio proučavanjem Roma, posebno u kontekstu njihova jezika. On je 1906. u Pljevlji napisao rukopis gramatike romskog jezika naslovljen Grammatik der zigeunerischen Sprache (Dialect der Wander-Zigeuner des Novi- 
pazarer Sanğakes), no ovaj rukopis nije bio poznat više od stotinu godina nakon njegova nastanka. O pronalasku ovog rukopisa pisao je Nikola Rašić koji je pretpostavljao kako je Drašković vjerojatno surađivao s Marom Čop Marlet, a preko nje s drugim istaknutim romolozima i lingvistima (Rašić 2012a:615-659, 2012b:669-681). Za razliku od Rašića, Zoran Lapov smatra kako je Drašković bio "slabo upućen" u dotadašnju romologiju, posebice $\mathrm{u}$ istraživanje romskog jezika i gramatike što zapravo ostavlja prostor za detaljniju romološku analizu Draškovićeva rada (Lapov 2012:701). Zoran Lapov u lingvističkoj je analizi Draškovićeve gramatike istaknuo kako ona "predstavlja važnu sponu u proučavanju kulturnih, jezičnih i drugih odlika Roma Gurbeta" te "značajan doprinos općoj romologiji” (ibid.:691-756).

Krajem 19. stoljeća započeo je projekt Odbora za narodni život i običaje Jugoslavenske akademije znanosti i umjetnosti u kojem je prikupljana i proučavana građa vezana uz tradicijsku kulturu južnih Slavena. Jedan dio njihova rada odnosio se na prikupljanje građe vezane uz istraživanje jezika, kulture, vjere i običaja Roma, od koje je dio objavljen, no znatan dio građe nije do danas objavljen i čuva se $\mathrm{u}$ arhivu Odbora $\mathrm{u}$ Zagrebu (Šimunović-Petrić 1988:37-67). Antun Radić metodološki je odredio istraživanje sastavljajući Osnovu za sabiranje i proučavanje građe o narodnom životu unutar koje se dio odnosi na sakupljanje građe o Romima (Radić 1997:40, 81). Sakupljači su većinom bili svećenici i učitelji koji su u prvoj polovini 20. stoljeća objavili niz djela dajući vrijedne etnografske prinose o Romima. Između ostalih "sakupljača", potrebno je spomenuti Luku Lukića koji je, opisujući slavonsko selo Klakarje, na tridesetak strana opisao život Roma te sastavio poseban dio teksta naslovljen Ciganjski govor $u$ selu u kojem donosi kratak pregled ciganske gramatike, izreke i pjesme te "hrvatsko-ciganjski" rječnik. Lukićev Hrvatsko-ciganski rječnik koji je nastao početkom 20. stoljeća na području Slavonije može se smatrati prvim romskim rječnikom na prostoru Hrvatske (Arhiv Odbora za narodni život i običaje, SZ 128b., Luka Lukić, Opis sela Klakarja (kotor Brodski, općina Klakaračka), god. rada: 1911., 1912. / SZ 128c., god. rada: 1911., 1912. / NZ 28c., god. rada: 1905.-1952.; Lukić 2016). Iz navedenog se može zaključiti kako su objavljena građa u Zborniku za narodni život $i$ običaje te rukopisne zbirke $u$ arhivu Odbora za narodni život i običaje iznimno bogat izvor za proučavanje povijesti Roma, i to ne samo na području Hrvatske nego i na području susjednih zemalja (Vojak 2004-2005:207-236). 
Razvoj suvremene kriminologije od kraja 19. stoljeća u Europi na određeni se način odrazio među kriminolozima koji su se bavili znanstvenim proučavanjem Roma. Potrebno je spomenuti Cesarea Lombrosa koji je krajem 19. stoljeća utemeljio kriminalnu biologiju, a u svojim djelima analizirao kriminalitet kod Roma smatrajući ih "prirođenim kriminalcima" i "rasom kriminalaca" prema kojima je bilo potrebno donijeti ponajprije preventivne represivne mjere što će posebice biti prihvaćeno među njemačkom kriminalnom biologijom (Illuzzi 2010:424-425; Widmann 2007:19-29). Na tragu ovakvog promišljanja o kriminalitetu Roma potrebno je spomenuti Hansa Grossa koji je postavio temelje kriminalistike $\mathrm{i}$ to posebice djelom Handbuch für Untersuchungsrichter als System der Kriminalistik (Priručnik za istražnog suca kao sustav kriminalistike) koje je 1893. izdano u Münchenu (Hrvatska enciklopedija 2000:256). U hrvatskom kontekstu potrebno je spomenuti Milana Mizlera koji je kao satnik u Hrvatskom oružništvu napisao 1909. djelo Istražna služba: priručnik za žandarme kao i u opće za sve organe javne sigurnosti po prof. dr. H. Grossu unutar kojeg je analizirao "ciganski kriminalitet” (Mizler 1909a.). Zanimljivo je napomenuti kako je iste godine Mizler objavio separat iz ovog djela naslovljen Cigani, njihova svojstva $i$ vještine u Oružničkom glasniku (Mizler 1909b:153-184). Iz samog naslova uočljivo je kako je Mizler uvelike koristio djela Hansa Grossa koji se smatrao jednim od utemeljitelja ("pionira") kriminalistike. Mizler opisuje Roma kao osebujna i okorjela kriminalca koji je istodobno jako strašljiv i poznat po kukavičluku, spreman na izdaju svoje braće, uhođenje i doušništvo, a s druge je strane iznimno lukav, dosjetljiv, s odličnom orijentacijom u prostoru. Štoviše, Mizler ističe Roma kao prepredenog i "kukavnog” ubojicu, prirođenog grabežljivca pripravna učiniti svaki zločin u bilo kojem trenutku. Iz Mizlerova viđenja može se primijetiti rasističko poimanje Roma; on smatra da Romi nisu ljudi nego neka posebna bića s iznimnim regenerativnim moćima. Tako Romi iznimno dobro podnose bol, a rane na njihovu tijelu ubrzano zacjeljuju. Također, primjetno je Mizlerovo uočljivo rasističko poimanje Roma kao "rođenog" kriminalaca (ibid. 184).

Posljednji hrvatski znanstvenik koji na određeni način zaključuje prvo razdoblje romoloških istraživanja od osoba koje su hrvatskog podrijetla ili su živjele na hrvatskim područjima, bio je Franjo Fancev. On je u Narodnim novinama u studenome 1912. objavio pet članaka 
Iz prošlosti i sadašnjosti cigana u kojima je analizirao povijest, jezik i kulturu Roma u Hrvatskoj i Europi. Ovih pet članaka mogu se smatrati dotad jednim od ponajboljih znanstvenih priloga romološkom istraživanju. Naime, uočljivo je kako je Fancev nastojao interdisciplinarnim pristupom obuhvatiti područja povijesti, jezika i književnosti te kulture Roma. On je pritom koristio relevantnu romološku literaturu, posebice radove Potta, Miklošiča i nadvojvode Josipa. Fancev je na početku rada istaknuo kako je povijest Roma "vrlo tamna" i da se "dugo nije znalo tko su njihovi srodnici". Zatim se složio s tezom o indijskom podrijetlu, a zanimljivo je kako je istaknuo da su migracije Roma prema europskom području potaknute ekonomskim razlozima ("bijedom"). Posebno analizira kulturu i običaje Roma ističući njihovu tradicionalnu muzikalnost. Značajan je i njegov osvrt na percepciju Roma u djelima europske i hrvatske književnosti te značenje Roma u europskoj književnosti. Osim navedenog, analizirao je tadašnji položaj Roma u Hrvatskoj dijeleći ih prema načinu života i zanimanjima te argumentirano kritizirajući neuspješnost hrvatskih vlasti u utvrđivanju njihova broja u popisima stanovništva zbog nedovoljno precizne metodologije. Znatan dio prostora posvetio je analizi njihova jezika, posebice leksika i gramatike. Svoju analizu završava isticanjem potrebe uređenja romskog života te zaključuje kako

"kod nas [u Hrvatskoj, op. a.] nije još ništa učinjeno [u proučavanju Roma, op. a.] (...) kako je kod nas još posvemašnje nepoznavanje cigana, hrvatska literatura ne poznaje nijednog dijela o ciganima, to bi svakako bila poželjna jedna knjiga, koja bi se opširnije bavila prošlošću i jezikom cigana, njihovim običajima, narodnim blagom uopće i napose ciganima koji stanuju medju nama. Toj potrebi rado bi udovoljio pisac ovih redaka, kad bi znao da će naći i odziva" (Fancev 1912:3).

Prema dostupnim podacima, može se istaknuti kako nitko od nadležnih hrvatskih vlasti nije podupro Fanceljevu želju da se detaljnije pozabavi proučavanjem povijesti i jezika Roma, no njegovi su romološki prilozi značajni jer je među prvima koristio interdisciplinarni pristup i rezultate filoloških, etnoloških, književno-povijesnih i demografskih istraživanja (Vojak 2005:421-438). 


\section{ZAKLJUČAK}

Romsko naseljavanje Europe od 14. stoljeća i njihov suživot s tamošnjim stanovništvom potaknuo je dio znanstvenika na proučavanje njihove povijesti, kulture, jezika i običaja. Prvi znanstveni prilozi o Romima istaknuli su njihovo egipatsko podrijetlo što će se promijeniti tek krajem 18. stoljeća kada će neki znanstvenici, poput Heinricha M. G. Grellmanna, na osnovi analize romskog jezika dokazati indijsko podrijetlo i utemeljiti romološka istraživanja. U 19. stoljeću romološka istraživanja produbljivala su spoznaje o jeziku i kulturi Roma i ponajprije su bila pokrivena folklorističkim i lingvističkim istraživanjima, a ona sama dobivaju krajem istog stoljeća institucionalni oblik oko društva The Gypsy Lore Society. Istodobno, u Njemačkoj tada započinje korištenje znanstvenih spoznaja o Romima za represivno-asimilacijsku politiku prema njima što će svoj vrhunac imati za vrijeme nacističke vlasti. U takvom europskom romološkom kontekstu potrebno je promatrati istraživanja o kulturi, jeziku i povijesti Roma od istraživača koji su vezani uz hrvatska područja. Tako su znanstvenici u Hrvatskoj već od 18. stoljeća pokazivali interes za proučavanje Roma, koje je započelo s lingvističkim prinosima Filipa Vezdina i analizom gospodarskog položaja Roma Ivana Škrleca Lomničkog. Od 19. stoljeća veći broj romoloških radova u Hrvatskoj odnosio se na analizu romskog jezika u djelima Antuna Mihanovića i Ivana Broza koji su slijedili tadašnja shvaćanja o indijskom podrijetlu Roma, pritom treba spomenuti rad Ljudevita Draškovića u romskoj gramatici. Spridon Jović nastojao je interdisciplinarnim pristupom analizirati Rome u slavonskim područjima Vojne krajine, dok se Mijat Stojanović većinom bavio istraživanjem narodnih poslovica i pripovijetki gdje je analizirao i one koje se odnose na Rome. Etnologinja Mara Čop Marlet, zajedno s etnologom Friedrichom S. Kraussom te etnomuzikološkim istraživanjima Franje Kuhača predstavljali su izravnu poveznicu s romolozima u Europi. Njima treba pridodati etnološke radove o Romima Bajašima (Koritarima) Ferde Hefelea. Ne treba smetnuti s uma prvi historiografski rad o Romima Emilija Laszowskog i kriminološku analizu Roma Milana Mezlera. Prvo razdoblje romoloških istraživanja završilo je znanstvenim prinosima o Romima koje su istražili suradnici okupljani oko Odbora za život i običaje južnih Slavena unutar tadašnje Jugoslavenske akademije znanosti i umjetnosti te radovima Franje Fanceva koji je 1912. u Narodnim novinama 
objavio dotad najdetaljniju analizu povijesti, kulture, običaja i jezika Roma u Hrvatskoj. Iz navedenog se može ustvrditi kako su navedeni romološki prinosi s hrvatskih područja činili tek manji, a nimalo neznačajni, dio tadašnjeg razvoja romologije u europskim zemljama.

\section{LITERATURA}

ABOUT, Ilsen i Anna ABAKUNOVA. 2015. Part 1: Annotations to the Bibliography on the Genocide and Persecution of Roma and Sinti; Part 2: Bibliography on the Genocide and Persecution of Roma and Sinti. Berlin: International Holocaust Remembrance Alliance. Berlin: IHRA. https://www.holocaustremembrance.com/ sites/default/files/ann_bib_long.pdf (pristup 25.6.2017.).

BARTOLOMEO, Fra Paolino da s. 1796. Viaggio alle Indie orientali, umiliato alla santità di n.s. papa Pio Sesto, pontefice massimo. Rome: Antonio Fulgoni.

BAUMGARTNER, Gerhard, Mirjam KAROLY, Lars LINDGREN, Martina MASCHKE i Karen POLAK. 2015. Roma Genocide: Overview of International Organisations working on historical and contemporary issues. Berlin: International Holocaust Remembrance Alliance.

BOSANSKI HRVAT. 1891. "Karavlasi ili Rumunji”. Glas Hercegovca, 21. siječnja, br. 4:2.

BROZ, Ivan. 1886. Crtice iz hrvatske književnosti. Zagreb: Matica hrvatska.

CROWE, David M. 1996. A History of the Gypsies of Eastern Europe and Russia. New York: St. Martin's Griffin.

ĐORĐEVIĆ, Dragoljub B. 2007. “Romologija”. U Sociološki rečnik, prir. Aljoša Mimica i Marija Bogdanović. Beograd: Zavod za udžbenike, 500-502.

ĐORĐEVIĆ, Dragoljub B. 2010. Na konju s laptopom u bisagama: uvod u romološke studije, Niš: Mašinski fakultet Univerziteta u Nišu ; Novi Sad: Prometej.

ERCEG, Ivan. 2000. "Opis fizičko-političkog položaja Ugarskog (i Hrvatskog) kraljevstva". Acta historico-oeconomica, vol. 27:41-178.

FANCEV, Franjo. 1912. "Iz prošlosti i sadašnjosti cigana". Narodne novine, 16. studenoga, br. 266:3; 18. studenoga, br. 267:3; 19. studenoga, br. 268:3; 20. studenoga, br. 269:3; 21. studenoga, br. 270:3.

FRASER, Angus. 1995. The Gypsies. Oxford: Wiley-Blackwell.

GRANT, Anthony P. 1999. "Romani in the Wilderness: On the Marginalisation of Romani within General Linguistics in Britain and America, and Some Consequences of The 'Rise Of The Amateur'”. Grazer Linguistische Studien, vol. 51:65-81. http:// unipub.uni-graz.at/gls/periodical/titleinfo/1913071 
HANCOCK, Ian. 1994. "Romani”. U The Encyclopedia of language and linguistics, vol.

7. Oxford - New York - Seoul - Tokyo: Pergamon Press, 3604.

HEFELE, Ferdo. 1890. “Koritari”. Vienac, vol. 22:742-743.

HEFELE, Ferdo. 1891. “Koritari”. Glas Hercegovca, 7. veljače, br. 8:1-2.

HEFELE, Ferdo. 1894. "Nešto o ciganluku”. Narodne novine, 24. ožujka, br. 69:3.

HEFELE, Ferdo. 1905. "Koritari”. Samoborski list, 1. listopad, br. 19:1-2.

HEUSS, Herbert. 2006. "Njemačka politika progona Cigana 1870.-1945.”. U Romi u Drugom svjetskom ratu: od 'rasne znanosti' do logora, vol. 1, ur. Karola Fings, Herbert Heuss i Frank Sparing, Zagreb: Ibis-grafika, 1-26.

HRVATIĆ, Neven i Suzana IVANČIĆ. 2000. "Povijesno-socijalna obilježja Roma u Hrvatskoj”. Društvena istraživanja, vol. 9/2-3(46-47):251-266. http://hrcak.srce. $\mathrm{hr} / 20268$

HRVATSKA ENCIKLOPEDIJA. 2000. "Kriminalistika”. Zagreb: Leksikografski zavod Miroslav Krleža, vol. 6, 256.

HRVATSKI ENCIKLOPEDIJSKI RJEČNIK. 2003. “Romologija”. Zagreb: Novi liber, 1142.

ILLUZZI, Jennifer. 2010. "Negotiating the 'state of exception': Gypsies' encounter with judiciary in Germany and Italy, 1860-1914". Social History, vol. 35:424-425. https://doi.org/10.1080/03071022.2010.515707

JANKO SPREIZER, Alenka. 2010. “Zadrege poimenovanja Ciganov/Romov, polja njihovega proučevanja in socialna antropologija Ciganov/Romov". Monitor ZSA, vol. 12/1-2(35-36):83-131.

JAUK-PINHAK, Milka. 1989. "Povijest izučavanja romskog jezika u Svijetu”. U Međunarodni naučni skup Jezik i kultura Roma, ur. Milan Šipka. Sarajevo: Institut za proučavanje nacionalnih odnosa, 11-20.

JEMBRIH, Alojz. 1996. “O Mihanovićevoj jezikoslovnoj i diplomatskoj djelatnosti”. U Antun Mihanović i njegovo doba: zbornik radova sa znanstvenog skupa u Klanjcu 7. lipnja 1996., ur. Božica Pažur. Zagreb: Kajkavsko spravišče, 121-143.

JOVIĆ, Spiridon. 2004. Etnografska slika slavonske vojne granice: [posvećeno 200-godišnjici Prvog srpskog ustanka]. Beograd: Čigoja štampa.

KOPERNICKI, Isidore. 1889. "The Dialect of the Bosnian Gypsies”. Journal of the Gypsy Lore Society, vol. 1:125-131.

KRAUSS, Friedrich S. 1886. Smailagić Meho: pjesan naših muhamedovaca. Dubrovnik: Knjižarnica D. Pretnera.

KRAUSS, Friedrich S. 1907. Zigeunerhumor: 250 schnurren, schwänke und märchen. Leipzig: Deutsche Verlagsactiengesellschaft.

KRAUSS, Friedrich Salomo. 1995. "Die 'Zigeunerforschungen' von Köhler-Zülch”. Fabula, vol. 36:230-242. 
KRAUSS, Friedrich S. 1999. Die vereinigten Königreiche Kroatien und Slavonien: mit zahlreichen Abbildungen im Texte und einem Titelbilde. Wien: Archiv Verlag.

KUHAČ, Franjo. 1875. "Budnica Trenkovih pandura (po glasbovanju bosanskih cigana u kajde stavio i za glasovir priredio Franjo Š. Kuhač)". Vienac, 24. travnja, br. 17:268.

KUHAČ, Franjo S. 1878. Južno-slovjenske narodne popievke, knj. 1, vol. 1. Zagreb: Knjigotiskarna i litografija C. Albrechta.

KUHAČ, Franjo S. 1880. Južno-slovjenske narodne popievke, knj. 3, vol. 1. Zagreb: Knjigotiskarna i litografija C. Albrechta.

KUHAČ, Franjo S. 1881. Južno-slovjenske narodne popievke, knj. 4, vol. 1-2. Zagreb: Knjigotiskarna i litografija C. Albrechta.

KUHAČ, Fr.[Franjo] Š.[Šaverij]. 1885. Pjevanka: sto dječjih popievaka za jedno grlo: s napjevi, tekstom i metodičkim uvodom: za pučke škole i zabavišta. Zagreb: Hrv. pedagogijsko-književni sbor.

KUHAČ, Franjo. 1896. Porietlo i umieće hrvatskih pučkih pjevača i glazbara. Zagreb: Knjigotiskara i litografija C. Albrecht (Jos. Wittasek).

KUHAČ, Franjo. 1898. “Turski živalj u pučkoj glazbi Hrvata, Srba i Bugara”. Glasnik Zemaljskog muzeja u Bosni i Hercegovini, vol. 10:211.

KUHAČ, Franjo S. 1904. Moj rad. Popis literarnih i glazbenih radnji od god. 1852.-1904. Zagreb: Tisak Antuna Scholza.

KUHAČ, Franjo. 1907. "Narodne osebine u gestama i karakteristika pojedinih naroda". Hrvatsko kolo, vol. 3:208-248.

LAPOV, Zoran. 2012. “O romskom jeziku zabilježenom rukom Louisa Draskovicha sandžački zapadnogurbetski govor”. U Hrvatske Indije 3, ur. Zdravka Matišić. Zagreb: Odjel za orijentalistiku Hrvatskoga filološkog društva, 691-756.

LASZOWSKI, Emilije. 1894. "Povjestna crtica o ciganima". Narodne novine, 15. rujna, br. 211:4-5.

LUCASSEN, Leo, Wim WILLEMS i Anne-Marie COTTAAR. 1998. Gypsies and Other Itinerant Groups: A Socio-Historical Approach. London: St. Martin’s Press.

LUČIĆ, Nikša. 2001. "Prilog biografiji Nikole Škrleca Lomničkoga”. U Nikola Škrlec Lomnički 1729-1799, vol. 2, ur. Eugen Pusić et al. Zagreb: Hrvatska akademija znanosti i umjetnosti, Hrvatski državni arhiv, Filozofski fakultet, Pravni fakultet, $101-111$.

LUKIĆ, Luka. 2016. Opis sela Klakarje: pripovijetke i pjesme skupljane od sredine 19. do sredine 20. stoljeća. Zagreb: Hrvatska akademija znanosti i umjetnosti ; Klakar: Općina Klakar.

LUNAČEK, Valdemar. 1999. "Hrvatski kameralist Nikola Šklec Lomnički”. U Nikola Škrlec Lomnički 1729-1799, vol. 1, ur. Eugen Pusić et. al. Zagreb: Hrvatska akademija znanosti i umjetnosti, Hrvatski državni arhiv, Filozofski fakultet, Pravni fakultet, 421-466. 
MARGALIT, Gilad. 2002. Germany and its Gypsyies: a Post - Auschwitz Ordeal. Madison: University of Wisconsin Press.

MATRAS, Yaron. 1999. "Johann Rüdiger and the Study of Romani in 18th Century Germany". Journal of the Gypsy Lore Society, 5th series, 9:89-116.

MAYALL, David. 2004. Gypsy Identities 1500-2000: From Egipcyans and Moon-men to the Ethnic Romany. London - New York: Routledge.

MIZLER, Milan. 1909a. Istražna služba: priručnik za žandarme kao i u opće za sve organe javne sigurnosti po prof. dr. H. Grossu. Zagreb.

MIZLER, Milan. 1909b. "Cigani, njihov svojstva i vještine”. Oružnički glasnik, vol. $3: 153-184$.

OČAK, Jelena. 1998. Antun Mihanović. Zagreb: Nakladni zavod Globus.

PLEŠE, Branko. 2002. "Hefele, Ferdo". U Hrvatski biografski leksikon, mrežno izdanje, Zagreb. http://hbl.lzmk.hr/clanak.aspx?id=7366 (pristup 25. 6. 2017.).

RADIĆ, Antun. 1997. Osnova za sabiranje i proučavanje građe o narodnome životu. Zagreb: Dom i svijet.

RAŠIĆ, Nikola. 2012a. “Ljudevit Drašković - prvi hrvatski romolog?”. U Hrvatske Indije 3, ur. Zdravka Matišić. Zagreb: Odjel za orijentalistiku Hrvatskoga filološkog društva, 615-659.

RAŠIĆ, Nikola. 2012b. "Bilježnice Ljudevita Draškovića”. U Hrvatske Indije 3, ur. Zdravka Matišić. Zagreb: Odjel za orijentalistiku Hrvatskoga filološkog društva, 669-681.

SEKULIĆ, Ante. 1999. "Razmišljanja Ivana Filipa Vezdina”. Prilozi za istraživanje hrvatske filozofske baštine, vol. 25/1-2(49-50):191-204. http://hrcak.srce.hr/76494

STOJANOVIĆ, Mijat. 1866. Sbirka narodnih poslovicah, riečih i izrazah. Zagreb.

STOJANOVIĆ, Mijat. 1881. Slike iz domaćega života slavonskog naroda i iz prirode. Zagreb.

ŠIMUNOVIĆ-PETRIĆ, Zorica, 1988. "Popis rukopisa u arhivu Odbora za narodni život i običaje". U Spomen-spis povodom obilježavanja stogodišnjice postojanja $i$ rada Odbora za narodni život i običaje južnih Slavena u sastavu Jugoslavenske akademije 1888-1988, ur. Andre Mohorovičić. Zagreb: Jugoslavenska akademija znanosti i umjetnosti, Odbor za narodni život i običaje, 37-67.

ŠKRLEC LOMNIČKI, Nikola. 1999. "Projectum Legum motivatum in Objecto Oeconomiae Publicae et Commercii perferndarum”. U Nikola Škrlec Lomnički 1729-1799, vol. 1, ur. Eugen Pusić et. al. Zagreb: Zagreb: Hrvatska akademija znanosti i umjetnosti, Hrvatski državni arhiv, Filozofski fakultet, Pravni fakultet, 89-418.

ŠKRLEC LOMNIČKI, Nikola. 2007. "Status actualis Economiae publicae, opificiorum et manufacturarum, vectigalis tricesimalis, fundi publici et commercii". U Nikola 
Škrlec Lomnički 1729-1799, vol. 4, ur. Eugen Pusić et al. Zagreb: Hrvatska akademija znanosti i umjetnosti, Hrvatski državni arhiv, Filozofski fakultet, Pravni fakultet, 379-681.

VELIKI RJEČNIK HRVATSKOG JEZIKA. 2003. "Romologija”. Zagreb: Novi liber, 1349.

VODNIK, Branko. 1910. “Antun Mihanović: 'Iz preporodnih studija' dra. Branka Drechslera”. Hrvatsko kolo, vol. 6:3-25.

VOJAK, Danijel. 2004.- 2005. “'Zbornik za narodni život i običaje’ i rukopisne zbirke arhiva Odbora za narodni život i običaje kao izvor za proučavanje povijesti romskog stanovništva na području Hrvatske u razdoblju od kraja XIX. stoljeća do danas". Etnološka tribina, vol. 27-28:207-236. http://hrcak.srce.hr/27608

VOJAK, Danijel. 2005. "Doprinos Franje Fanceva u proučavanju povijesti romskog stanovništva na prostoru". Društvena istraživanja, vol. 14/3(77):421-438. http:// hrcak.srce.hr/17692

VOJAK, Danijel. 2010. “O proučavanju Roma u hrvatskoj znanosti i kulturi ili postoji li hrvatska romologija?”. Historijski zbornik, vol. 63/1:215-240. http://hrcak.srce. $\mathrm{hr} / 81686$

VOJAK, Danijel. 2013a. "Iz povijesti Roma u 18. stoljeću: Nikola Škrlec Lomnički o Romima u spisima Status actualis, Projectum i Descriptio". Zbornik Odsjeka za povijesne znanosti Zavoda za povijesne i društvene znanosti Hrvatske akademije znanosti i umjetnosti, vol. 31:197-215. http://hrcak.srce.hr/121323

VOJAK, Danijel. 2013b. U predvečerje rata: Romi u Hrvatskoj 1918. - 1941. Zagreb: Romsko nacionalno vijeće, Udruga za promicanje obrazovanja Roma u Republici Hrvatskoj "Kali Sara”, 2013.

VOJAK, Danijel. 2014. "The Nazi Genocide of the Roma. Reassessment and Commemoration, ur. Anton Weiss-Wendt, Berghahn Books, New York - Oxford, 2013., 272 str.”. Časopis za suvremenu povijest, vol. 46/1:195-201. http://hrcak. srce.hr/122143

VOJAK, Danijel. 2016. “Osvrt na izložbu 'Romi u koncentracijskom logoru Jasenovac' autora Ive Pejakovića u Javnoj ustanovi Spomen-područje Jasenovac 2016. godine". Historijski zbornik, vol. 69/2:608-610. http://hrcak.srce.hr/176724

VRANJICAN, Stjenko. 2007. “Znanstveni projekt 'Nikola Škrlec Lomnički (1729-1799) i njegovo doba' - dostignuća i perspektive”. U Nikola Škrlec Lomnički 1729-1799, vol. 4, ur. Eugen Pusić et al. Zagreb: Hrvatska akademija znanosti i umjetnosti, Hrvatski državni arhiv, Filozofski fakultet: Pravni fakultet, 1-22.

WIDMANN, Peter. 2007. "The campaign against the restless: criminal biology and the stigmatization of the Gypsies, 1890-1960". U The Roma: a Minority in Europe: Historical, Political and Social Perspectives, ur. Roni Stauber i Raphael Vago. Budapest: CEU Press, 19-29. 
WILLEMS, Wim. 1997. In search of the true Gypsy: From Enlightenment to Final Solution. London - New York: Routledge.

ŽURA VRKIĆ, Slavica. 2003a. Život i književno djelo Mare Čop. Magistarski rad. Zagreb, Filozofski fakultet u Zagrebu.

ŽURA VRKIĆ, Slavica. 2003b. "Prva hrvatska etnografkinja Mara Čop Marlet". Ethnologica Dalmatica, vol. 12:5-34. http://hrcak.srce.hr/107914

\section{IZVORI}

Arhiv Odbora za narodni život i običaje, Odsjek za etnologiju, Hrvatska akademija znanosti i umjetnosti, SZ 128b., Luka Lukić, Opis sela Klakarja (kotor Brodski, općina Klakaračka), god. rada: 1911., 1912. / SZ 128c., god. rada: 1911., 1912. / NZ 28c., god. rada: 1905.-1952.

Hrvatski državni arhiv, HR-HDA-806, Osobni fond Emil Laszowski, 1.5.1.17. Uspomene na ljude, Mara Čop-Marlet.

Danijel Vojak

\section{THE BEGINNINGS OF CROATIAN ROMOLOGY: FROM FILIP IVAN VEZDIN TO FRANJO FANCEV}

Romology represents a scientific discipline which studies the history and the culture of the Roma people. With the first romological research studies published in the 16th century in Western Europe, the Croatian academics produced their first romological research papers in the second half of the 18th century. The linguistic research efforts of Filip Vezdin may thus be considered in such context: as he tried to prove the Indian origin of Roma, his contemporary Ivan Škrlec Lomnički analysed the situation of Roma in Hungary from the economic perspective. In the first half of the 19th century, Antun Mihanovic pursued a linguistic analysis of the Romani language, while Spiridon Jović analysed the position of Roma on the territory of the Military Frontier in Croatia. In the second half of the 19th century, Mijat Stojanović published several ethnographic research papers, while the most prominent romologist of this period, Mara Čop Marlet, published her ethnographic research alongside dramaturgical and literary works of Roma. Moreover, Mara Čop Marlet inspired further interest for Roma by engaging researchers such as Franjo Kuhač and Emilij Laszowski who published the first Croatian historiographical study on Roma. Friedrich S. Krauss significantly contributed to the ethnographic research of Roma while Ivan Broz and Ljudevit Drašković analysed the Romani language. Ferdo Hefele studied Koritari as a special group of Roma of the Romanian origin. In addition, the Committee on 
Folklife and Customs of the Yugoslav Academy of Sciences and Arts promoted consistent ethnographic research in Croatia. Finally, the First World War marked the end of the first period of romological research in Croatia with the research efforts of Milan Mizler and Franjo Fancev.

Keywords: Roma, Romology, Croatia, history, scholarship

\section{DÎM KAPU A LU HRVATSKI ROMOLOGIJI: DĂ LA FILIP IVAN VEZDIN PÎN LA FRANJO FRANCEV}

Romoligiji ka una dă ćiljin znastvenă disciplină înđiriptată îj pă la ku totu învăcală a lu romilor historiji šî kultură. Nasălăla a lu romilor stanovniś îm pămîntu dă la Europa dă la XIV.st. u bîntălit šî interesu a lu znanstveniś dă a lor învăcari. Aša élši istraživačkă prinosur dă historiji šî kulturi a lu Romilor objavalići îm XVI.st. šî aje la zapadnăeuropskă znanstveniś. Îm alta parći dă XVIII. stoljeći zabilježići îs élši prilogur dă Romi dă la pojedinc kari or fost poreklom Hurvec uli atunśe kusta pă područje a lu pămîntu a lu hurvécilor. Îm ala kontekst să poći promatrali doprinosurlje a lu Filip Ivan Vezdin šî lu Ivan Škrlec Lomničar.

Îm élši parći dă XIX.st. or sljedilit doprinosurlje a lu Antun Mihanović šî lu Spiridon Jović, kînd îm alta parći dă XIX. st. văzut îj maj balour interesu a lu znanstveniś kit să să învéci dă Romi, šî aje la Mijat Stojanović, Mara Čop Marlet, Franjo Kuhač, Emilij Laszowski, Friedrich S. Krauss, Ivan Broz, Ljudevit Drašković, Ferdo Hefele. Sustavnă etnografskă istraživanjur la gata dă XIX.st. provodulé Odboru dă lu narodnă kust šî običajur a lu Jugoslavenska akademija dă šćući šî umjetnošći, îm kari mulc istraživačur, ka Luka Lukić, Vatroslav Rožić šî Vladimir Ardalić, značajno or pridonijelit la pirśipală a lu historiji, kulturi šî ljimba a lu Romilor. Élši romološkă razdoblji îm Hurvăćije u fost gata ku lu Élši tabăra lu lume-cara šî ku djelurlje a lu Milan Mizler šî Franjo Fancev.

Ključnă vorbi: Romi, romologiji, Hurvăćije, historije, šćući

\section{EŠIRDAEHRVATSKERE ROMOLOGIAKERE: E FILIPIVAN VEZDINESTAR DŽI FRANJO FANCEV}

I Romologia sar ulavdi sadžanipaski (džantripaski) disciplina dromardi si ko sikljovipa e sahnipaskoro katar i romani historia thaj kultura. O thanardipe e romane seliskoro (populaciakoro) ane europakere thema katar o XIV. šeliberš vazdinda thaj intereso e sažanutnengoro (džantrengoro) vašo rodljaripe savo sas phandlo e Romenca. Adžukhar e 
jekhto rodljaripaskere xramovipa vaši historia thaj kultura e Romengiri ikaldi si ano XVI. šeliberš thaj kodova ke lunale europakere rigakere rodljarutne. Ano dujto kotor e XVIII. šeliberšeskoro xramome si e jekhto rodljaripaskere xramovipa vaše Roma katar e individue save so sas kustikipastar Hrvatia vaj ano kodova vaxt dživdinenas ke reonoja katar e hrvatskakere phuva. Ano kodova konteksto šaj te oven dikhle e xramovipa save so dende o Filip Ivan Vezdin thaj o Ivan Škrlec Lomnički. Ano jekhto ekvašipe e XIX. šeliberšeskoro aven e xramome butja save so kerde o Antun Mihanović thaj Spiridon Jović, džikaj ano dujto ekvašipe e XIX. šeliberšeskoro dikhle si e zurarde rodljaripaskere interesia vašo rodljaripe e Romenge thaj kodova ko Mijat Stojanović, Mara Čop Marlet, Franjo Kuhač, Emilijo Laszowski, Friedrich S. Krauss, Ivan Broz, Ljudevit Drašković, Ferdo Hefele. E sistematikane etnografikane rodljaripa ko agor e XIX. šeliberšeskoro kerda i Komisia vašo selikano dživdipe thaj adetia e Jugoslaviakere akademiakoro vašo sadžanipe thaj arto, savate andre but rodljarutne sar so si Luka Lukić, Vatroslav Rožić thaj Vladimir Ardalić, dende but baro xaljovipe (haćaripe) e historiake, kulturake thaj čhibjake e Romengoro. O jekhto romologikano periodo ani Hrvatska agordja e Jekhto Dunjajakere maripasa thaj e xramovipasa katar o Milan Mizler thaj Franjo Fancev.

Klidarde lava: Roma, Romologia, Hrvatska, historia, sadžanipe

Radovi objavljeni $\mathrm{u}$ časopisu nalaze se $\mathrm{u}$ otvorenom pristupu i mogu se distribuirati u skladu s odredbama licencije Creative Commons Imenovanje-Nekomercijalno-Bez prerada 4.0 (https://creativecommons.org/licenses/by-nc-nd/3.0/hr).

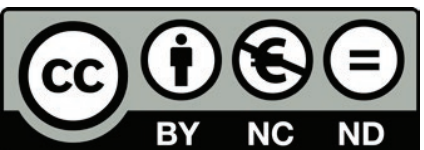

BY NC ND
Articles published in this journal are Open Access and can be distributed under the terms and conditions of the Creative Commons license Attribution-NonCommercial-NoDerivatives 4.0 (http://creativecommons.org/licenses/by-nc-nd/4.0/) 